\title{
MIDDLE TEST ILMU SEJARAH
}

Nama : Muhammad Ilmiyanor

NIM : : 1910128210029

Program Studi : Pendidikan IPS (A2)

Mata Kuliah : Ilmu Sejarah dan Pendidikan IPS

\section{Pernyataan 1}

Pada Bab I buku Sejarah Pendidikan Indonesia (Era Pra Kolonialisme Nusantara sampai Reformasi) dijelaskan bahwa pendidikan di Nusantara telah dimulai jauh sebelum system persekolahan ada. Selanjutnya ketika pengaruh budaya asing masuk ke nusantara pendidikan tersebut mengalami perkembangan.

a. Kemukakan fakta sejarah yang menyatakan bahwa pendidikan telah ada sebelum sistem persekolahan ada.

Fakta sejarah yang menyatakan Bukti pada masa peninggalan Raja Mulawarman Abad 4-5), peninggalan berupaya padalam tulisan Pallawa bahasa Sanskerta, dari tulisan tersebut dapat diketahui bahwa di Jawa Barat pernah berdirinya Kerajaan Tarumenegara, prasasti tersebut didirikan oleh para pendeta dari golongan Brahmana, pada masa itu mereka saja yang dapat membaca kitab suci seperti kitab Weda, golongan ii yang dapat menggunakan Bahasa sanskerta dan huruf Pallawa sebagai bahasa resmi, sehingga hal itu dapat Pada dikatakan padamasa itu pendidikan hanya ditunjukan pada golongan yang berkasta tinggi saja

Pada masa kerajaan Sriwijaya menjadi kuat dan jaya karena perdagangannya ab oegawai dapat menjalankan kapal, perdagangan meminta pendidikan praktis dan langsung dapat dipakai dalam perniagaan. Setelah beberapa lalu muncullah Dubu, tempat berguru ilmu yang praktis untuk berdagang, lambat laun Sriwijaya menjadi pusat pengetahuan. Dalam ini ibu kota sriwijaya terletak di pertengahan jalan Tiongkok- Indian pusat perniagaan dan kebudayaan pada waktu itu, menjadi pusat pertemuan saudagar asing dan pendeta-pendeta, ibu kota merupakan tempat menuntut ilmu yang perlu untuk perdagangan, Sebagai pusat pengajaran Budha.

Di candi borobodur terlihat lukisan yang menggambarkan suatu sekolah seperti yang berlaku pada wakru sekarang, seorang Brahmana duduk dilingkari oleh murid- 
muridnya, membawa buku belajar membaca menulis, tiggal bersama-sama dengan Brahana dalam suatu rumah, Gurunya tidak mendapat gaji, dijamin siswanya untuk hidup. Buku-buku para siswa terdiri dari daun lontar ( seperti yang ada di museum Bali) buk-buku inilah memberikan bukti bahwa bangsa kita pada waktu itu telah pandai membaca Bahasa Sanskerta dan menunjukan adanya pengajaran dan belajar dalam pendidikan pada waktu itu. Dasar pendidikan dan pengajaran adalah agama Buddha atau Brahma. Hal tersebut adanya Buddha atau Brahma di Jawa Tengah( Borobodur ). Berhubungan dengan perkembangan pendidikan dan pengajaran di Mataram kuno ini berita dari tiongkok mengatakan bahwasebelum Sanjaya telah ada kebudayaan Hindu, Terbukti dari adanya relief Candi Prambanan dihias dengan riwayat Sri Rama engan lengkap berdasarkan hal-hal di atas pelajaran yang diberikan oleh para Brahmana kepada para siswa :

a. Agama Buddha dan Brahma,

b. Kepustakaan Mahabrata dan Ramayana,

c. Filsafat dan Etika,

d. Kesenian ( bangunan,lukisan an pahat ),

e. Ketuhanan,

f. Kenegaraan,

g. Ilmu bangunan ( candi-candi).

h. Ilmu pasti dan ilmmu alam, memungkinkan diadakannya perhitunganperhitungan mengenai pembangunan candi.

Sistem Pendidikan tinggi telah digambarkan pada keadaan sekitar abad ke-4 sampai abadke-8 , Pada abad-abad terakhir menjelang jatuhnya kerajaan Hindu di Indonesia, Sistem pendidikan tidak lagi dijalankan secara besar-besaran, tetapi dilakukan oelh umama guru kepada siswa dalam jumlah terbatas dipedepokan. Siswa selain diajarkan ilmu yang bersifat spiritual religious tetapi juga diajarkan ilmu pengetahuan yang bersifat umum.

2. Pendidikan di indonesai pada zaman Penyebaran Islam,

Bahwa pesantren memiliki hubungan historis dengan Timur Tengah, informasi ini berasal dari mereka yang melakukan ibadah Haji, tidak sekedar melakukan ibadah tetapi juga menuntut ilmu, terutama menghadiri pengajian di Masjidil Haram dan Masjid Nabawi, pengajian serta pelaksaan ibadah selain berhaji, diadopsi para kiai 
mendirikan pendidikan serupa di Tanah Air. Di Pesantren dianjarkannya berbagai kitab Ilmu klasik dalam bidang fiqih, teologi, dan tasawuf Seorang menteri dari dunia arab Nizam El-Mulk abad ke- 11 sebagai pendiri pendidikan Madrasah. Peralihan dari agama Hindu/Budhha menuju Islam umumnya berlangsung secara damai.ketika agama islam masuk Indonesia, pengaruh dan cara berpikir Hindu masih kuat, pada masa itu ada dua tipe guru,pertama guru untuk kalangan keratin mengajar pada putra raja dan kesatria lain, keu=dua guru pertapa jauh dari keramaian belajar sertam mendalami ilmu-ilmu ketuhanan serta ilmu lainnya.

Di Aceh Pada Masa Kerajaan Aceh Darussalam terdapat beberapa lemabaga pendidikan Islam anatara lain :

1) Pendidikan Meunsah Tingkat pendidikan Islam terendah berfungsi sebagai sekolah dasar.

2) Sebagai tempat upacara keagamaan, penrimaan dan tempat penyaluran zakat, penyelesaian mengenai perkara agama, musyawarah dan penerimaan tamu.

3) Mengajarkan pelajaran membaca Al- Qur'an

2). Pendidikan rangkang

Di bangun oada setiap pemukiman biasanya berdekatan dengan masjid untuk mempermudah peserta didik untuk shalat berjamaah, pada zaman dulu masjid hanya terdapar pada setiap pemukiman, jumlah rangkaang di Aceh sama banyaknya dengan jumlah pemukiman pada waktu itu.

3). Pendidikan Dayah

Peserta didik pada tingkat dayah mereka telah menyelesaikan pendidikannya dirangkang.Belajar di dayah lebih man diri, Latihannya lebih banyak, seperti latiha berpidatodakwah, latihan berbicara, dengan Bahasa arab dan lainnya, hal ini dilakukan supaya murid lancar melakukan kegiatab dalam masyarakat.

\section{4). Pendidikan Dayah Teuku Chik}

Dayah Chik merupakan perguruan tinggi Islam sejak dulu, setiap kerajaan di Aceh memiliki Dayah Chik. Sejak tahun 840-1903 ( Masehi) lebih dari 50 buah d seluruh aceh, Kerajaan islam tersebut antara lain : 
a. Kerajaan Islam Peurelak

b. Kerajaan Islam Tamiang

c. Kerajaan Islam Dayah

d. Kerajaan Isla Banda Aceh Darussalam.

Syaharuddin, \& Susanto, H. (2014). Sejarah Pendidikan Indonesia (Era Pra Kolonialisme Nusantara sampai Reformasi). FKIP Universitas Lambun Mangkurat.

b. Kemukakan fakta sejarah yang menjelaskan bahwa masuknya budaya asing ke nusantara telah menyebabkan pendidikan mengalami perkembangan.

Fakta sejarah yang mengemukan bahwa masuknya budaya asing ke nusantara telah menyebabkan perkembangan hal tersebut menunjukkan ketika ibu kota kerajaan sriwijaya menjadi pusat perniagaan dan kebudayaan, hal itu menjadi pusat petemuan saudagar asing dan pendeta-pendeta yang di dalam perjalanan dari India ke Tiongkok, ibu kota tersebut merupakan tempat menuntut ilmu juga tempat dimana kaum agama bertemu dan bertukar pikiran.hal tersebut adanya membuktinya perkembangan dalam pendidikan terutama mengenai perdagangan, hal in terjadi karena di kota tersebut menjadi tempat menuntut ilmu sehingga kaum agama bertemu dan saling bertukar pendapat atau pemikirannya, hal tersebut menjadikan perkembangan karena dalam proses bertukar pendapat atau pikiran akhirnya dapat menemukan ilmu pengetahuan yang baru atau inovasi sehingga membuat adanya kemajuan dalam pendidikan terutama pada saat itu ilmu pengetahuan yang perlu untuk perdagangan.

Buktinya pada sejarah Tiongkok abad-19 atau ke -10 memperlihatkan tempar biara tempat pendeta agama menjadi semacam bank, ada pula menjadi tempat petemuan, demikian ibu kotA menjadi pusat agama pada saat bersamaan. Selanjutnya pada abad ke-7,ada seorang mahaguru sriwijaya yang termasyur bernama Dharmapala adalah guru besaryang pernah memberikan kuliah-kuliah pada "Universitas" Nalanda di Benggala selama 30 tahun. Perguruan tinggi yang adadiSriwijaya tidak kalah mutunya degan yang ada di tanah suci India, maka dari itu banyak teologi dan musafir bddha belajar pula disriwijaya, pada abad ke-7, Dharmapala datang di Sumatra dan emberikan pelajaran agama Buddha Mahayana ,yang semula menganut hinayana, keterangan ini di peroleh pada 672 dan $685 \mathrm{M}$ berdiam di palembangan untuk belajar, sehingga dikatakan bawa pendidikan pada masa itu memusatkan 
perhatiannya pada agama. Hal tersebut membuktikan fakta bahwa pendidikan di nusantara mengalami perkembangan dengan adanya seorang mahaguru Dharmapala yang datang di Sumatra ntuk memberikan pelajaran agama Buddha Mahayana kepada penduduk setempat, hal itu menjadikan pedidikan berkembang dan memusatkan perhatiannya pada agama.

Dalam hal ini universitas Nalanda menjadi pusat pengetahuan terkenal mempunyai pelajar yang terkenal dari tiongkok,jepang dan negara asia tenggara lainnya, maka tidaklah heran apabila ketika itu kesustraan di sriwijaya sudah tinggi tingkatanna karena adanya pengaruh tersebut dan raja sriwijaya menyuruh membuat jamus Bahasa daerah Sanskerta, pada abad ke-9M adanya meminta dari raja untuk pembangunan asrama yang digunakan sebagai tempat bagi para pelajar agama Buddha yang berasal dari sriwiaya.Berkembangnya pendidikan juga ada dari selian pengajaran agama para siswa mempelajari kepustakaan hindu seoerti mahabarata dan Ramayana, Terbukti dari relief tersebut candi Prambanan diahis dengan riwayat Sri Rama dengan lengkap, Pendidikan pada waktu ini telah teratur dengan baik mengutamakan budi pekerti dan kesusilaan, di bawah pimpinan Sanjaya, Mataram mengakami kemakmuran, tidak ada kriminal. Seorang guru bernama Wicawamitra merupakan seorang Brahmana, keahliaan sastra sangat tinggi, dia memberi pelajaran di sekolah rendah.

Sampai jatuhnya kerajan Hindu terakhir di Indonesia,yaitu Majapahit pada akhirnya abad ke-1, ilmu pengetahuan berkembang terus, khususnya sastram seperti kaling, medang, Mataram, Kediri, Singosari yang menghasilkan karya bermutu tinggi.

Sistem pendidikan tinggi telah berkembang digambarkan pada keadaan sekitar abadke-4 sampai abad ke -8, pada abad terakhir menjelang jatuhnya kerajaan Hindu di Indonesia.

Hal tersebut yang ada di atas menunjukkan ada nya perkembangan pendidikan pada zaman kerajaan-kerajaan yang ada di nusantara yang dibawa oleh asing sehingga menjadi peningkatan suatu pengetahuan tertentu terutama pada hal agama, sastra yang disebutkan di atas dan banyak pelajaran yang diberikan, 
2. Masuknya budaya asing menjadi Perkembangan Pendidikan Pada Zaman Penyebaran Islam

Fakta Sejarah mengemukakan mengenai perkembangan pendidikan pada zaman penyebaran islam dari pengaruh luar proses perkembangan tersebut melalui berbagai cara salah satunya melalui pendidikan, keberadaan pesantren versi lain menyebutkan bahwa pesantren memiliki hubungan historis dengan Timur Tengah, informasi ini berasal dari mereka yang melakikan ibadah haji, mereka disana tidak hanya sekedar melakukan ibadah haji tetapi juga menuntut ilmu terutama menghadiri pengajian di Masjidil Haram dan Masjid Nabawi, Proses belajar, pengajian serta pelaksanaan ibadah selain haji, diadopsi para untuk mendirikan pola pendidikan serupa di Tanah air, dalam fakta tersebut menggambarkan bahwa mereka ynag sedang melakukan ibadah haji sekaligus menuntut ilmu terutama ilmu agama diadopsi para kiai untuk mendirikan pola pendidikan serupa yag ada Tanah Air, hal itu adanya pengaruh serta perkembangan dalam pendidikan.

Pada pendidikan Madrasah seorang menteri dari dunia arab Nizam el-Mulk pada abad ke-11, tokoh ini mengadakan pembaharuan dengan memperkenalkan system pendidikan yang bermula bersifat murni teologi atau ilmu ketuhanan dan menambah ilmu-ilmu yang bersifat keduniawian seperti astronomi dan ilmu obat-obatan, halini dikaitkan dengan kemunculan di Indonesia merupakan peralihan dan perkembangan pendidikan islam yang mengadopsi system pendidikan modern dengan tetap mempertahankan beberapa pelajaran pokok islam lebih banyak diajarkan, hal ini merupakan adanya perkembangan dalam dunia islam terutama dalam pendidikan, adanya seorang orang luar nusantara menteri arab Nizam el-Mulk dengan menambkan ilmu-ilmu yang bersifat keduniawian, hal tesebut mepengaruhi pendidikan di nusantara dan mengalami peningkatan

Syaharuddin, \& Susanto, H. (2014). Sejarah Pendidikan Indonesia (Era Pra Kolonialisme Nusantara sampai Reformasi). FKIP. Universitas Lambun Mangkurat. 
c. Uraikan dampak sosial masuknya budaya asing ( Hindu-Budha dan Islam) kenusantara terhadap perkembangan pendidikan di nusantara dan apakah materi tersebut dapat dijadikan referensi dalam pembelajaran IPS di SMP

dampak sosial masuknya budaya asing Hindu-Buddha terhadap perkembangan pendidikan di nusantara yaitu adanya perkembangan berdasarkan agama, karena terdapat hal yang memberikan dampaknya terhadap perkembangan pendidikan tersebut berpusat pada agama yang di anut oleh pribumi nusantara karena berpusat pada religi ajaran agama hindu dan Buddha,sehingga adanya dampak kepada masyarakat setempat dalam melakukan perkembangan apabila ditinjau dari peninggalan sebuah batu tertulis pada abad $4-5$ menunjukkan adanya pengaruh agama siwa dikalangan masyarakat setempat pribumi nusantara. Pada kerajaan sriwijaya memberikan dampak terhadap kotanya menjadikan pusat perniagaan dan kebudayaan ibu kota tersebut menjadi kota tempat menuntut ilmu dalam untuk perdagangan, dan kaum agama bertemu dan bertukar pikiran, hal tersebut adanya menunjukkan dampak sosial terhadap masyarakat kota karena menjadi tepat pusat menuntut ilmu, munculnya dubu, kota tempat berguru ilmu pratis untuk berdagang, akhirnya lambat laun sriwijaya menjadi pusat pengetahuan.

Pada permulaan abad 11 kerajaan Sriwijaya, rajanya bernama Sri Cudamaniwarman untuk mengahadapi ancaman dari jawa, maka mengadakan hubungan persahabaran dengan cina dan cola, hal ini menunjukkan adanya bentuk asosiasi kerjasama dikerajaan memiliki hubungan interaksi dengan yang lain agar menghasilkan dampak yang positif.

Di candi borubodur terlihat lukisan menggambarkan suatu, hubungan antara seorang guru dan murid yang baik, muridnya tinggal bersama dengan Brahmana, gurunya tidak mendapat gaji tetapi dijamin oleh siswa untuk hidup, dalam hal ini memberikan dampak sosial saling menguntung satu sama lain, seperti seorang Brahana mengajarkan pengetahuan dan mendapatkan jaminan oleh siswanya untuk hidup, sedangkan siswanya sendiri mendapatkan ilmu pengetahuan dari gurunya.

Pendidikan pada waktu itu telah teratur dengan baik danpendidikan pada waktu itu mengutamakan budi pekerti dan kesusilaan, hal ini mengajarkan tentang normanorma dan moral yang berlaku dimasyarakat terutama pada budi pekerti dan 
kesusilaan tersebut berdampak pada kehidupan sosialnya yang telah diatur dengan baik dalam menuntut ilmu hal ini akan berdampak kepada masyarakat atau individu karena dari hal itu akan menimbulkan perilaku yang positif sehingga berdampak baik pada diri sendiri maupun orang lain. Dampak sosial terjadi Pada saat dibawah pimpinan Sanjaya, Kerajaan Mataram mengalami kemakmuran, dan tidak ada criminal karena ada suatu perkembangan tertentu pada dunia ilmu pengetahuan pada saat itu, dalam zaman itu juga kepustakaan Jawa Kuno telah berkembang,

Pada zaman Airlangga, kebudayaan mendapat perhatian pada masa itu, terbitlah buku Arjuna Wiwaha, akan tetapi rakyat biasa belum dapat menikmatinya, pendidikan hanya untuk keluarga raja yang nantinya akan memegang pemerintahan, adanya suatu ketimpangan sosial pada masyarakat karena pada saat itu hanya keluarga raja yang mendapatkan pendidikan yang akan melanjutkan pemerintahan selanjutnya dalam hal itu ada perbedaan dalam pendidikan antara keluarga raja dengan rakyat biasa sehingga menimbulkan dampaknya masing-masing. Pada pemerintahan Jayabaya kebudayaan telah mendapatkan perharian hal ini menunjukan adanya corak kebudayaan jawa dan Bahasa jawa kuno yang tidak dipegaruhi oleh agama hindu atau Buddhadan menurut ajaran-ajaran moral.

Pada abad ke-8 terakhir menjelang jatuhnya kerajaan hindu di Indonesia, padepokan selain diajarkan ilmu pengetahuan umum juga diajarkan ula ilmu-ilmu bersifat spiritual religious, mereka harus bekerja memenuhi kebutuhan hidup sehari-hari.

\section{Dampak sosial pada Zaman Penyebaran Islam}

Pada abad ke-13 banyak yang memeluk agamahindu kemudian agama islam, mungkin sekali agama isam mereka telah menyesuaikan dengan keadaan dan adatistiadat dan mungkin menjadi kebudayaan hindu. Hal tersebut adanya pengaruh dari agama islam tersebut sebelumnya masyarakat memeluk agama hindu lalu kemudian menjadi agama islam, hal tersebut berdampak pada masyarakat mungkin karena keadaan telah disesuaikan dengan adat istiadat setempat. Dalam belajar murid di langgar tidak dipunggut biaya misalkan diberikan tergantung kepada kerelaannya seperti memberikan tanda mata berupa benda-benda atau uang. Dalam hal tersebut ketika tidak dipungut uang sekolah menjadikan murid menjadi hemat dalam memenuhi kebutuhan sehari-harinya, dan disni mempunyai bentuk mengargai satu sama lain terutama pada guru tersebut. 
Disana ada tujuan dipisahkan dari orang tua dan keluarga hal tersebut agar berdampak baik pada mereka belajar hidup mandiri sekaligus meningkatkan hubungan dengan kyai dan juga hubungan kepada tuhan.

Dalam materi tersebut dapat dijadikan sebagai referensi dalam pembelajaran IPS di SMP, karena ada berbagai dampak-dampak sosial yang positif yang memberikan pengaruh terhadap masyarakat sedangkan dalam pembelajaran IPS berpengaruh pada perubahan yang ada pada peserta didik. Pertama mengenai dampak sosial dalam suatu kota yang aa di atas tersebut sehingga menjadi kota pusat pengetahuan sehingga hal tersebut berdampak baik pada dirinya sendiri dan orang lain, dalam pembelajaran IPS dapat kita jadikan referensi pertama mengembangkan suatu hal melalui metode bertukar pikiran atau pendapat sehingga mampu melihat perkembangan yang ada pada peserta didik.

Hal lain seperti dalam materi tersebut ada raja yang mengadakan hubungan kerja sama dengan yang lain, hal tersebut dapat dijadikan karena hal tersebut sangat berdampak positif karena dalam bekerja sama dapat meningkatkan kebersamaan, kekeluargaan, serta memperkuat silaturahmi, materi yang lain berkaiatan dengan perkembangan yan sesuai dengan nilai IPS secara kita ketahui bahwasanya tujuan Pendidikan IPS menjadikan warga negara yang baik, dalam materi tersebut ada yang berkenaan dengan budi pekerti dan kesusilaan hal itu merupakan suatu hal yang dapat membawa dampak positif terhadap dirinya dan orangnya, hal ini dapat dijadikan rujukan dalam pembelajaran IPS mengutamakan Moral atau adabnya dalam berperilaku kepada diri sendiri maupun orang lain sehingga membawa dampak yang baik, sebagai seorang guru IPS menjadikan tauladan dan contoh yang baik merupakan hal utama seperti moral, budi pekerti dan mempunyai adab yang baik disertai ilmu yang bermanfaat. Materi tentang kebudayaan islam mengenai yang saya catat di atas seperti mandiri dalam berbuat sesuatu hal itu akan membawanya dampak yang bagus karena mampu dapat mengintropeksi dirinya dapat lebih kenal dengan tuhannya. Dalam hal itu pembelajaran IPS di SMP terutama mengajarkan kemandirian termasuk hal yang utama karena dengan hal itu mampu melakukan sesuatu dengan percaya diri dengan baik serta dapat pengalaman dan bermanfaat bagi dirinya untuk belajar sesuatu pada peserta didik semisalnya.

Syaharuddin, \& Susanto, H. (2014). Sejarah Pendidikan Indonesia (Era Pra Kolonialisme Nusantara sampai Reformasi). FKIP Universitas Lambun Mangkurat. 


\section{Pernyataan 2}

Pada bab II buku Sejarah Pendidikan Indonesia (Era Pra Kolonialisme Nusantara sampai Reformasi) dijelaskan bahwa masuknya bangsa Barat ke Nusantara telah membawa banyak perubahan, tidak terkecuali dalam dunia pendidikan.

a. Bagaimana Pengaruh masuknya bangsa Eropa ke Nusantara terhadap perkembangan pendidikan Nusantara.

Masukknya bangsa Eropa ke Nusantara terhadap pendidikan nusantara memberikan pengaruh pada abad permulaan ke-16, bangsa portugis eropa yang pertama datang ke nusantara disamping disana mereka berdagang sekaligus, menyebarkan agama Katolik didatangkan para misionaris, untuk menyebarkannya ini mereka mendirikan sekolah, Pada tahun 1536 di Ternate mendidik calon misionaris, didirikan di pulau Solor. Pengaruhnya tersebut banyak anak- anak Indonesia yang masuk sekolah ini dengan usaha tesebut juga berpengaruh terhadap orang-orang Maluku kehidupannya menjadi maju, disana diajarkan membaca, menulis dan berhitung muridnya mencapai 50 orang, murid yang dari bumiputra ternyata dapat mengikuti dan ingin melanjutkan studi di Goa, pusat kekuatan portugis. Dalam hal tersebut adanya pengaruh masuknya bangsa eropa dari portugis terhadap perkembangan pendidikan yang ada di nusantara banyak anak-anak yang masuk dan muridnya dapat mengikuti dan melanjutkan studinya, hal tersebut dengan kedatangan portugis selain berdagang mereka juga menyebarkan agama dan mendirikan sekolah ternyata berpengaruh pribumi dari nusantara dapat melanjutkan pendidikannya di Goa. Tapi dalam penyebaran agama katolik di kepulauan Maluku demikian dengan penyelenggaran pendidikan tidak banyak mengalami kemajuan karena hal tersebut terjadi adanya hubungan orang portugis dengan sultan ternate kurang baik, dan mereka harus bersaing dan beperang melawan bangsa asing lainnya orang spanyol dan kemudian orang-orang inggris.

Selanjutnya pendidikan pada masa penjajahan belanda, dalam penjajahan belanda ini menunjukan adanya menerapkan kebijakan pendidikan yang diskriminatif dan menghalangi pertumbuhan lokal yang sudah ada, mereka beragama Kristen Protestan sambil berdagang sekaligus menyebarkan agamanya, sekolah-sekolah dirikan di Pulau Ambon dan Pulau Bacan (Maluku), disana belum mengajarkan pengetahuan umum, Bahasa yang digunakan dalam pengatar dengan Bahasa melayu, baru pada 
kelas yang lebih tinggi dipakai Bahasa belanda, dari pihak belanda mendirikan sekoah bagi calon pegawai VOC. Pada tahun 1299 jatuhnya VOC karena bekerja tanpa disiplin, bahwasanya sekolah-sekolah telah banyak berdiri secara formal tidak didirikan atas namaVOC, tetapi didirikan dari kalagan agama Kristen Protestan. Sehingga mempunyai corak dan ciri-ciri Kristen, gambaran beberapa sekolah seperti di Ambon terdapat 33 sekolah dengan 1300 Murid, daerah Maluku Utara/Barat laut terdapat 39 sekolah dengan 1057 murid, di luar Maluku sekolah Batavia,dan sekolah baru didirikan lebih luas meliputi Pulau Jawa. Dari pernyataan tersebut belanda menyebarkan agama dan mendirikan sekolah dibeberapa wilayah Indonesia yang bercorak dan berciri hal itu mempengaruhi pada pendidikan yang ada di Indonesia terutama pada masyarakat pribumi, pada yang sudah dicatat di atas terdapat beberapa sekolah yang berdiri dan memiliki banyak muridhal tersebut ternyata masukkanya bangsa eropa dari belanda mempengaruhi pada pendidikan di Indonesia banyaknya bediri sekolah-sekolah terutama ada di pulau jawa, Maluku dan lain-lain.

Lanjutnya masuknya bangsa Eropa ke nusantara memberikan pengaruh terutama tentang masalah pendidikan pada tahun 1799 usaha-usaha pendidikan kolonial Belanda yang diajarkan di daerah Maluku tidak dapat meluas ke daerah lain maka pada saat pemerintahan Hindia Belanda mulai dijalankan pendidikan bagi bangsa Indonesia belum baik. pada akhir abad ke-18 dan awal abad ke-19 sistem ini dirubah menjadi sistem klasikal dimana pengajaran diberikan kepada sekelompok anak-anak pada waktu yang sama dengan bahan pelajaran yang sama pada permulaan abad tersebut didirikan sekolah kelas 1 yang lamanya 5 tahun sekolah ini disediakan pada anak-anak dari lingkungan pegawai pamong praja ditempatkan di kota-kota kepresidenan pada akhir abad ke-19 didirikannya sekolah kelas 2 yang lamanya minimal 4 tahun setelah itu dapat disimpulkan bahwa hanya kecerdasan bangsa Nusantara atau Indonesia pada waktu itu masih rendah ada beberapa sekolah swasta tapi keadaannya masih dia bagus guru yang mengajar hanya tamatan sekolah kelas 1 dan kelas 2.

pada tahun 1867 dan pemerintahan Hindia Belanda dibentuk suatu departemen tersendiri yang mengurusi masalah pendidikan agama dan kerajinan yang disebut departement Van Onderwijs En Eeredienst jurnal hal tersebut agar produk Bumiputera Cina dan golongan lainnya beri kesempatan dalam memperoleh 
pendidikan barat sebagai dasar pendidikan sampai pendidikan tinggi. Pada tahun tersebut pemerintahan Belanda sudah memikirkan tentang mengurusi masalah pendidikan pada tahun 1667

Dalam hal lain juga pengaruh dari Eropa berpengaruh pada pendidikan rendah, dan pada pendidikan lanjutan adanya sekolah umum, sekolah warganegara tinggi. pada selain sekolah ada juga pendidikan menjadi seorang guru dalam pengaruh tersebut pertama ada untuk sekolah desa ada sistem magang ada kursus dan menerima murid dari sekolah atau sekolah kelas II , hal yang lain memberikan tentang pendidikan kejuruan dalam hal ini dapat mempertinggi bidang ekonomi rakyat yang dilaksanakan pelajaran praktis yang pertama didirikan pada tahun 1881 adanya sekolah pertukangan dan ada sekolah teknik ada pendidikan dagang pendidikan pertanian pendidikan kejuruan kewanitaan pendidikan sekolah sekolah tinggi pendidikan kejuruan pendidikan sekolah tapi tinggi pendidikan tinggi hukum pendidikan tinggi teknik.

Pernyataan di atas tersebut memberikan tentang bahwasanya kedatangan dari Eropa dari bangsa Belanda tersebut atau bangsa Eropa dari Portugis dan yang lain-lain memberikan pengaruh yang memberikan pengaruh pada dunia pendidikan banyak sekolah-sekolah yang berdiri banyak pilihan kursus-kursus yang berdiri.

Syaharuddin, \& Susanto, H. (2014). Sejarah Pendidikan Indonesia (Era Pra Kolonialisme Nusantara sampai Reformasi). FKIP Universitas Lambun Mangkurat.

b. Berdasarkan pemaparan pada Bab II, Konsep IPS apa saja yang dapat digunakan untuk melihat/mempelajari rangkaian peristiwa sejarah tersebut.

Menurut saya Konsep IPS yang dapat digunakan dalam mempelajari rangkaian peristiwa sejarah tersebut yaitu melalui konsep dasar IPS antara lain :

Pertama, dari Ilmu Sosial, Dari konsep pendidikan IPS dari segi ilmu sosial untuk mempelajari peristiwa dalam bab tersebut mempelajari tokoh yang ada pada sejarahnya tersebut sebagai makhluk sosial tidak lepas dari interaksi menjadi bagian dari masyarakat atau pribumi dalam peristiwa sejarah itu yang dibentuk tersebut. Seperti pada seorang tokoh penyebar agama pada masa penjajahan eropa dari portugis, spanyol hingga belanda dalam segi ini meninjau dari tokohnya tersebut bagaimana tokohnya tersebut berbaur atau berinteraksi pada masyarakat pribumi nusantara, seperti pada tokoh bernama Antonio Galvano mendirikan sekolah untuk 
anak-anak dari pemuka pribumi dalam tokoh tersebut ilmu sosial berperan dalam mempelajari dan mengetahui dari segi ia berinteraksi pada masyarakat pribumi sehingga dapat menimbulkan pengarah pada masyarakat setempat, hal seperti itu mengapa dapat mempengaruhi pada masyarakat nusantara dari segi untuk mengetahui bagaimana dia melakukannya pada tokoh tersebut. Jadi pada konsep ini berkaiatan pada tokoh sejarah tersebut.

Kedua, dari Studi Sosial, dalam konteks ini beranggapan adanya suatu bidang tentang gejala dan masalah sosial yang terjadi, jadi hal konsep ini mempelajari dari rangkaian sejarah mengenai masalah-masalah yang terjadi seperti pada seorang tokoh dari belanda "Gubernur Daendels bahwa perlu diselenggarakannya pengajaran bagi anak-anak Jawa untuk memperkenalkan tentang kesusilaan, adat istiadat dan pengertian agama-agama, akan tetapi cita-cita Daendels tidak dapat direalisasi,berhubungan tidak adanya anggaran untuk pengajaran bagi bangsa Indonesia," mengapa hal tersebut terjadi permasalahan dalam konteks sejarah tersebut ternyata "berganti ketika dalam konteks internasional mereka dikalahkan inggris" dan dari sudut lain ada juga mengenai "penyebaran penyelenggaran pendidikan yang dilakukan oleh portugis penyebaran agama katolik di kepulauan Maluku tidak banyak mengalami kemajuan karena selian hubungan orang-orang portugis dengan sultan Ternate kurang baik, mereka bersaing melawan orang-orang spanyol kemudian orang inggris." Dalam pada pernyataan tersebut pada peristiwa sejarah dalam konsep studi sosial adanya suatu permasalahan atau gejala yang terjadi dalam masyarakat atau lingkungannya karena ada sesuatu hal yang tidak sesuai, maka dari itu IPS berperan dalam menjadikan warga negara yang baik melalui dari pemecahan masalah-masalah yang terjadi.

Ketiga, konsep selanjutnya berkaitan dengan disiplin ilmu yang ada ada pendidikan IPS sebagai himpunan dan integral dari dari sejumlah mata pelajaran menjadi terpadu, dalam hal konsep ini berguna untuk menyatakan pada konteks peristiwa sejarah tersebut.

1. Geografi,

Geografi menjadi sudut pandang pada suatu ruang tertentu berkaiatan dengan lokasi, apabila dipelajari dalam konteks sejarah pendidikan Indonesia seperti pada kalimat berikut dalam hal ini memberikan gambaran pada pengaruh barat dari segi 
pendidikannya seperti "Pulau-pulau lainnya yang juga telah ada sekolah seperti Pulau Timor(1710), Pulau Sawu (1756), Pulau Kei ( 1635), Pulau Kisar, Pulau Wetar, Pulau Damar, dan Pulau Letti (1700)". Hal tersebut menyatakan ada suatu tempat atau ruang gambaran permukaan bumi yang berhubungan dengan sejarah tersebut konsep ini menjadi hal yang penting juga pada sejarah karena dala sejarah harus ada suatu tempat/peristiwa yang terjadi.

\section{Antropologi}

Dalam hal ini berkaitan pada masyarakatnya seperi budaya-budaya hal ini berkaiatan dengan peristiwa sejarah ini mengenai budaya eropa dan budaya nusantara, dalam sejarah tersebut seperti budaya jawa, Maluku dan lain-lain.

\section{Ekonomi}

Konsep ini berguna dalam menanggapi peristiwa terutama tentang Sejarah Pendidikan Indonesia, sebagaimana orang eropa yang menjajah nusantara untuk mencari rempah, da juga adanya Sistem VOC atau monopoli yang sangat mempengaruhi pada perekonomiannya. Teks tersebut sebagai berikut "bangsa belanda mendirikan perkumpulan dagang yang terkenal dengan namaVOC. Mereka melakukan monopoli perdagangan ,tidak hanya rempah-rempah saja, tetapi hasil bumi Indonesia diperjualbelikan." Dalam konteks tersebut adanya hubungan dengan perekonomian dalam mencapai kepuasan atau tujuan tertentu dalam hal ini berkaiatn dengan konsep IPS sebagai disiplin ilmu.

\section{Sosiologi}

Secara kita ketahui bahwasanya konsep ini mempelajari tentang masyarakatnya dan interaksi yang terjadi,dalam sejarah tersebut adanya suatu masyrakat pribumi sebagai pedagang yang saling berinterkasi antara satu dengan yang lainnya karena ada kontak dan komunikasi serta suatu pesan yang disampaikan, dalam bab sejarah tersebut adanya suatu bangsa eropa yang datang ke nusantara memberikan pengaruh terhadap masyarakatnya hal itu mereka lakukan dari segi interaksi melalui kontak ataupun komunikasi serta sesuatu hal yang diinginkan atau tujuan yang dicapai dalam pesan mereka tersebut.

\section{Politik}


Hal ini berkaitan dengan suatu tatanan kekuasaan, dan kewenangan yang ada, dalam hal ini berkaiatan pada yang kita pelajari dengan peristiwa sejarah ini, contoh pada teks adanya "pengaruh politik etis terhadap perkembangan pendidikan di Indonesia, Faktor lain kemunculan Politik Etis ini adanya partai liberal yang berpengaruh, dalam pemerintahan Hindia Belanda dibentuk suatu departemen tersendiri yang mengurusi masalah pendidikan, agama dan kerajinan yang disebut Departement Van Onderwijs En Eeredienst (Departemen Pengajaran dan Kepentingan Kehormatan)." Hal tersebut berhubungan dengan politik karena berkaitan dengan kewenangan dan kekuasaan pada bagian yang ada pada pendidikan pada saat itu.

\section{Psikologi}

Pada konsep ini berkaitan dengan pemikiran individu atau kelompok tertentu apabila dikaitkan dengan Sejarah Pendidikan Indonesia maka meninjau dari segi pemikirannya terutama pola pikir pada pribumi nusantara pada pendidikan pada masa penjajahan tersebut sehingga mengalami perubahan, dan mengetahui pemikiran pola pikir dari para orang eropa yang memberikan pengaruh pada masyarakat pribumi mengenai pendidikan.

\section{Sejarah}

Berkaiatan dengan kejadian yang ada dimasalalu dan peristiwa tersebut unik untuk dipelajari salah satunya seperi Sejarah Pendidikan Indonesia, hal ini berkaitan dengan waktunya, serta ruang atau peristiwa yang terjadi pada masa itu dan perubahan pada pendidikan yang ada dinusantara serta ada tokoh atau pelakunya dalam sejarah tersebut.

Jadi, Konsep ilmu IPS dalam kaitannya dengan peristiwa sejarah tersebut mempelajari dari masalalunya dari segi tokoh, peristiwa dan waktunya, yang diambil dari segi ialah makna dari peristiwa tersebut mengambil hikmah serta pelajaran yang disampaikan sebagaimana tujuan IPS untuk menjadikan warga negara yang baik. Jawaban yang ada di atas ini berkaitan dengan menurut dari pendapat saya sendiri.

Syaharuddin, \& Susanto, H. (2014). Sejarah Pendidikan Indonesia (Era Pra Kolonialisme Nusantara sampai Reformasi). FKIP Universitas Lambun Mangkurat. 